\title{
PREMA TEORIJSKIM ISHODIŠTIMA I PRIMJENI MODELA RUKOVOĐENJA U KNJIŽNICAMA
}

\author{
TOWARDS THEORETICAL BACKGROUNDS AND \\ APPLICATION OFMANAGEMENT MODELS IN LIBRARIES
}

\author{
Antal Balog \\ Veleučilište s pravom javnosti \\ „Baltazar“ Zaprešić \\ antal.balog@bak.hr
}

UDK / UDC [658: 005.7]: 021

Izvorni znanstveni rad / Original scientific paper

Primljeno / Received: 16. 8. 2019.

Prihvaćeno / Accepted: 1. 10. 2019.

\section{Sažetak}

Cilj ovoga rada jest uputiti na osnovne teorijske premise rukovođenja, razmotriti i objasniti osnovne aspekte rukovođenja u knjižnicama, funkcije rukovođenja i njihove posebnosti i međuodnose, te ulogu i doprinos stručnih tijela knjižnice u procesima rukovođenja. Također, cilj rada je pridonijeti boljem razumijevanju povezanosti funkcije rukovođenja s funkcijama upravljanja i izvršavanja.

Oblikovanje. U uvodnom se dijelu teksta razmatraju osnovni pojmovi rukovođenja na temelju teorijskih modela koje su razvili ekonomski stručnjaci, slijede objašnjenja pojedinih funkcija rukovođenja, kao što su planiranje, odlučivanje, organiziranje, kadrovsko popunjavanje, vođenje i kontrola. U nastavku slijede objašnjenja koja se odnose na sadržaj funkcije rukovođenja knjižnicom te objašnjenja osnovnih kategorija rukovođenja. Završni dio rada bavi se analizom simbioze (ili komplementarnosti) poslovnih i rukovodećih funkcija u knjižnici kao organizaciji i ustanovi uz prikaz osnovnih poslovnih aktivnosti rukovoditelja te očekivane opće vještine rukovoditelja.

Rezultati rada ogledaju se u jasnijem razlikovanju procesa funkcije rukovođenja u odnosu na funkcije upravljanja i funkcije izvršavanja te se ukazuje na važnosti usavršavanja rukovodećih praksi u hrvatskim knjižnicama kao ustanovama od posebnog društvenog interesa.

Vjesnik bibliotekara Hrvatske 62, 2(2019), 65-87

ISSN 0507-1925 
Praktična primjena. Sadržaj ovog članka može pridonijeti povećanju kvalitete rada ravnatelja i drugih rukovodilaca u knjižnici povećavajući njihova znanja i kompetencije u području rukovođenja te bolje razumijevanje njihovih nadležnosti i odgovornosti.

Društveni značaj ovog članka implicira unapređenje dobre prakse rukovođenja $\mathrm{u}$ knjižnicama kao ustanovama koje u svom radu objedinjuju važna društvena područja i imaju značajan utjecaj na kulturu, odgoj, obrazovanje, znanost, informiranje i zabavu te neizravan utjecaj na gospodarstvo, politički sustav, demokraciju itd.

Originalnost i vrijednost ovog rada ogleda se u produktivnom povezivanju saznanja dviju različitih znanstvenih disciplina, odnosno organizacije i menadžmenta te knjižničarstva, kao i u pojašnjavanju procesa rukovođenja u praksi.

Ključne riječi: funkcije rukovođenja, knjižnice, organizacija, rukovođenje knjižnicama.

\section{Abstract}

Purpose. The purpose of this paper is to explore and explain the basic aspects of management in libraries, its functions, peculiarities and inter-relations as well as the role and contribution of professional library bodies to the process of management. The additional goal of the paper is to foster a better understanding of the connection between the functions of management with those of governing and execution.

Design. The introductory part of the paper explores the fundamental management terms. It is followed by explanations of management functions such as planning, decision making, organizing, personnel recruitment, guidance, and control. This segment is followed by the explanations of the content of library management as well as the basic categories of management. The final part of the paper analyses the symbiosis (or complementarity) of business and management functions in a library as organisation/ institution with the discussion about basic business activities.

Findings. The paper facilitates better distinction between the function of management and those of management and execution. It also stresses the importance of improvement of the present management practices in Croatian libraries (as institutions of special social interest).

Practical implications. The content of this paper can improve the management quality of library directors and other library administrative personnel increasing their level of knowledge and competences in the area of management as well as contributing to better understanding of their responsibility and competence.

Social implications. The paper implies the improvement of good practice of management in libraries as institutions that incorporate in their activities important social areas and have significant influence on culture, education, science, information, and entertainment as well as indirect influence on economy, political system, democracy, etc. 
Originality/Value. The paper offers a productive connection of knowledge from two different scientific areas - organisation and management on the one, and librarianship on the other. It also offers an explanation of the management process in practice.

Keywords: library, library management, organization, functions of management.

\section{Uvod}

Upravljanje i rukovođenje dva su komplementarna poslovna procesa usmjerena na održivi razvoj, odnosno na organizacijsku uspješnost i učinkovitost bilo koje organizacije, pa tako i knjižnice. Kao javne ustanove i neprofitne organizacije knjižnice sadrže, uslijed odsutnosti tržišnih utjecaja, određene posebnosti u upravljanju i rukovođenju, kojih nema ili su manje prisutne u drugim, njima sličnim, organizacijama, odnosno ustanovama. ${ }^{1}$

Premda se pojmovi upravljanja i rukovođenja često smatraju sinonimima, dobro je podsjetiti da oni to nisu u potpunosti. Njihov međusoban odnos jest sljedeći: upravljanje - rukovođenje - izvršavanje. ${ }^{2}$ Upravljanje je poslovni proces kojim osnivač ili osnivači knjižnice utvrđuju osnovne determinante organizacije i funkcioniranja knjižnice, primjerice viziju, misiju, glavne ciljeve, opću organizacijsku strukturu, poslovne politike, strategije itd. Rukovođenje je, za razliku od ovako definirane funkcije upravljanja, operativna i izvršna funkcija temeljnih upravljačkih odluka. Koristeći se povezanim načelima, metodama i tehnikama, funkcija rukovođenja sadržana je u (1) organiziranju i usklađivanju, (2) planiranju, (3) odlučivanju, (4) kadrovskom popunjavanju, (5) vođenju i (6) kontroliranju aktivnosti u organizaciji. Rukovođenje usklađuje pobrojane sadržaje s glavnim ciljevima, strategijama i politikama knjižnice koje osnivači knjižnica utvrđuju preko svojih upravnih vijeća. Navedene funkcije ne odvijaju se sukcesivno, već simultano i međusobno su ovisne u različitim omjerima i intenzitetima.

Rukovođenje pojedinim aktivnostima u knjižnici provodi se operacionalizacijom poslanja i glavnih ciljeva i strategija tako što ih se derivira u parcijalne ciljeve i zadaće unutar uspostavljene organizacijske strukture uz koordinaciju racionalne uporabe materijalnih, nematerijalnih, financijskih, ljudskih i drugih resursa. ${ }^{3} \mathrm{Bu}-$

1 Sadržaj rada uglavnom se odnosi na knjižnice koje nisu u sastavu, s obzirom na to da rukovođenje u njima ima svoje posebnosti. Budući da su knjižnice u sastavu dio veće organizacijske strukture, primjerice gospodarskog subjekta, osnovne ili srednje škole, visokog učilišta, ustanove za znanost, istraživanje i razvoj itd., funkcija rukovođenja prilagođena je organizaciji poslovanja, kao i vrsti djelatnosti dotičnog pravnog subjekta.

2 Usp. „U smislu klasičnih organizacijskih znanosti, upravljanje (engl. administration, government) je proces u kojem vlasnik i/ili osnivač određuje sljedeće determinante: viziju i misiju (poslanje), opću organizaciju, politike kojima se ostvaruje poslanje organizacije, strategiju provođenja opće i pojedinačnih politika te glavne ciljeve organizacije.“ Balog, A. Upravljanje knjižnicom kao poslovna funkcija. // Vjesnik bibliotekara Hrvatske 61, 2(2018), str. 83.

3 Usp. Sikavica, P.; Novak, M. Poslovna organizacija. Zagreb: Informator, 1999. Str. 373-380. 
dući da se rukovođenje odvija u organizacijskom kontekstu, objasnimo ukratko pojam organizacije, odnosno pojam organizacijske strukture.

Najčešća definicija organizacijske strukture kaže da je to radna cjelina jednog broja osoba ili njihovih skupina, koja je uspostavljenja radi zajedničkog i koordiniranog ostvarivanja zadanih ciljeva ili zadataka. Uspostavom funkcionalne organizacijske strukture, odnosno dizajniranjem (oblikovanjem) organizacije, njezini ciljevi ili zadaće lakše se i brže postižu nego kada bi ih svaki pojedinac nastojao sam realizirati. Drugim riječima, organizacija značajno osnažuje pojedince i njihove skupine u postizanju organizacijskih ciljeva. Kada uspostavljena organizacija postane formalna i legalna, nastaju pravne osobe poput primjerice gospodarskih subjekata, vladinih ili nevladinih organizacija, gradskih, županijskih, državnih, međudržavnih i međunarodnih ustanova, pa tako i knjižnica.

Organizacijska praksa pokazala je kako traganje za uspostavom organizacijske strukture neke ustanove koja je jedina ispravna i najbolja moguća najčešće nije produktivna. Različite uspostavljene organizacijske strukture imaju različite prednosti i nedostatke. Svaka od njih prihvatljiva je sve dok je produktivna i dok optimalno zadovoljava ostvarivanje većine organizacijskih ciljeva. Važno je poštovanje nekoliko načela u organizacijskom ponašanju. Potrebno je organizacijsku strukturu učiniti transparentnom, odnosno razumljivom svim uposlenicima. Važno je da uposlenici znaju tko donosi odluke, osobito ključne i konačne odluke, da postoji značajna usklađenost odgovornosti i autoriteta (ovlaštenja) te da postoji načelo jednog nadređenog. Također, koliko je god moguće, treba izbjegavati uspostavljanje (pre)velikog broja organizacijskih razina rukovođenja. One smanjuju raspon kontrole i time olakšavaju rukovođenje pojedinim dužnosnicima, ali u komunikacijskim kanalima povećavaju informacijsku buku i mogu reducirati učinkovitost rukovođenja. ${ }^{4}$

Organizacijske strukture imaju svoje dimenzije kao što su (1) kompleksnost, (2) formalizacija i (3) decentralizacija. Kompleksnost ili organizacijska složenost pokazuje razvedenost organizacijskih dijelova (odjela, službi, odsjeka, timova itd.) raspoređenih po hijerarhijskoj visini i horizontalnoj širini. Najčešće se mjeri rasponom kontrole, odnosno brojem neposredno podređenih osoba jednom nadređenom te komunikacijskim opterećenjem. Formalizacija, kao dimenzija organizacijske strukture, označava količinu propisa koji reguliraju izvršavanje poslova te sadrži diskrecijsko pravo rukovoditelja na utvrđivanje normi i određivanje oblika i obrazaca organizacijskog ponašanja. Stupanj centralizacije (ili decentralizacije)

\footnotetext{
4 Drucker preporučuje traganje za optimalnom organizacijskom strukturom za određenu ustanovu koja odgovara glavnim ciljevima i zadacima. Pritom u jednoj ustanovi svoje mjesto mogu naći različiti modeli za različite vrste poslova, od linijskih, funkcijskih, matričnih, divizionalnih, fleksibilnih, projektnih, timskih i mrežnih do ad hoc organizacijskih struktura. Drucker, P. Najvažnije o menadžmentu: izbor iz radova o menadžmentu Petera F. Druckera. Zagreb: M.E.P. Consult, 2005. Str. 73.
} 
organizacijske strukture označava stupanj distribucije ovlasti za donošenje odluka na niže organizacijske razine.

Za knjižnice kao ustanove u hrvatskim se uvjetima može reći da u najvećem broju slučajeva imaju jednostavnu ili umjereno složenu organizacijsku strukturu, formalizacija rada im je relativno visoka, a upravljanje i rukovođenje organizacijom naglašeno je centralizirano. ${ }^{5}$ Takve organizacijske dimenzije u velikoj su mjeri prikladne poslanju i općim ciljevima koje knjižnice imaju. Tijekom duge povijesti svojega djelovanja knjižnice su uspjele optimalizirati svoje organizacijske strukture i sustave upravljanja i rukovođenja te ih međusobno uskladiti i prikladno normirati. Međutim stvarno organizacijsko ponašanje knjižnica u odnosu na regulacijski, organizacijski, upravljački, rukovodeći i poslovni normirani model najčešće nije u dovoljnoj mjeri usklađeno.

Kao jedan od značajnijih objektivnih razloga raskoraka između deskriptivnog i preskriptivnog organizacijskog ponašanja naših knjižnica može se, između ostaloga, navesti izvjestan nedostatak znanja, vještina, kompetencija i iskustva knjižničara u području organizacije, upravljanja i rukovođenja. Razlozi tog nedostatka svakako su mnogostruki, a možemo navesti neke: (1) ravnatelji knjižnica te rukovoditelji nižih razina u pravilu se angažiraju iz redova knjižničnih stručnjaka, koji u svome obrazovanju nisu dovoljno pripremani za rukovodeće pozicije; (2) u pogledu ljudskih potencijala (ili resursa) knjižnice najčešće nemaju potrebnu razinu cirkuliranja rukovodećih kadrova drugih, neknjižničarskih struka, primjerice ekonomskih; (3) odsustvo motiviranosti i objektivnih mogućnosti dodatnog i(ili) cjeloživotnog obrazovanja ravnatelja i drugih rukovodećih dužnosnika knjižnica u području organizacije, upravljanja i rukovođenja; (4) izvjesna razina nedovoljne zainteresiranosti osnivača knjižnica za reduciranje stvarnog u odnosu na normativno organizacijsko ponašanje knjižnica. ${ }^{6}$

\section{Sadržaji i funkcije rukovođenja knjižnicom}

Prema čl. 17. i 18. Zakona o knjižnicama i knjižničnoj djelatnosti knjižnicama preko deset uposlenika upravlja upravno vijeće koje ima sljedeće odgovornosti: (1) donosi plan rada i razvitka knjižnice, (2) razmatra izvršavanje plana rada i razvitka knjižnice, (3) odlučuje o financijskom planu i godišnjem financijskom izvještaju, (4) donosi statut i druge opće akte, (5) utvrđuje način i uvjete korištenja

\footnotetext{
5 Za nacionalni knjižnično-informacijski sustav u Republici Hrvatskoj može se reći da je u značajnoj mjeri decentraliziran, dok knjižnice imaju centraliziranu dimenziju.

6 Potreba boljeg organizacijskog ponašanja knjižnica povremeno je tema stručnih radova naših knjižničara. Usp. Markulin, H.; M. Šember.; J. Petrak. Medicinske knjižnice na putu prema promjenama. // Vjesnik bibliotekara Hrvatske 45, 3-4(2002), 51-57. Također, Line u svom „Općem izvješću o knjižnicama“ ukazuje na jedan broj menadžerskih problema prisutnih u europskim knjižnicama. Usp. Line, M.B. The universal library report. // Library mangement 17, 1(1996), 33-36.
} 
knjižnične građe, (6) odlučuje o promjenama u organiziranju rada knjižnice te (7) obavlja druge poslove određene Zakonom, drugim propisom, aktom o osnivanju i statutom knjižnice. ${ }^{7}$

U citirani Zakon nije unesena razlika između funkcije upravljanja i funkcije rukovođenja, tako da članak 19. citiranog Zakona kaže da knjižnicom upravlja ravnatelj koji ,predstavlja i zastupa javnu knjižnicu u pravnom prometu i pred tijelima državne vlasti te obavlja druge poslove predviđene zakonom, aktom o osni-

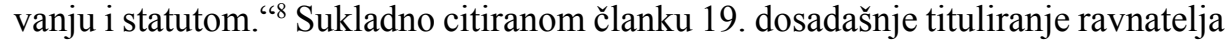
knjižnica trebalo bi se promijeniti u upravitelja knjižnice. Pritom bi razgraničenje funkcija upravnih vijeća knjižnica i upravitelja knjižnica postalo manje razvidno. Prema organizacijskoj teoriji i praksi poslovi koji se pripisuju ravnatelju po svojoj naravi jesu rukovodeći poslovi te će se taj termin koristiti u nastavku teksta.

U sadržajnom smislu područja rukovođenja u knjižnici mogu se svrstati u četiri osnovne skupine: ${ }^{9}$

(a) Rukovođenje poslovanjem, odnosno poslovnim procesima ili poslovnim funkcijama koje se mogu podijeliti na opće i posebne. ${ }^{10}$

(a1) Opće poslovne funkcije javljaju se u svim poslovnim subjektima ili u velikoj većini, primjerice poslovi računovodstva i financija, informacijskih tehnologija, pravni, kadrovski i opći poslovi, poslovi nabave i prodaje, održavanja, zaštite na radu i protupožarne zaštite itd. Toj skupini može se pribrojati rukovođenje organizacijskim i poslovnim promjenama, zatim rastom ustanove i njezinim razvojem, rukovođenje projektima, koordiniranje odnosa s dionicima itd.

(a2) Posebne poslovne funkcije odnose se na one poslovne procese koji su prema Nacionalnoj klasifikaciji djelatnosti 2007. (NKD 2007.) registrirani kod nadležnog trgovačkog suda kao poslovna djelatnost knjižnice. ${ }^{11}$ To mogu biti primjerice nabava knjižnične građe i izgradnja knjižničnih zbirki, stručna obrada knjižnične građe prema stručnim standardima, što uključuje izradu informacijskih pomaga-

\footnotetext{
7 Zakon o knjižnicama i knjižničnoj djelatnosti. // Narodne novine 17, 365(2019). [citirano: 2019-08-6]. Dostupno na: https://narodne-novine.nn.hr/clanci/sluzbeni/2019_02_17_356.html.

8 Ibidem., članak 19. st. 2.

9 Ova klasifikacija koristi dva kriterija: (1) kriterij poslovnih procesa organizacije i (2) kriterij resursa organizacije.

10 Poslovanje neke pravne osobe jest trajno, svjesno i svrsishodno obavljanje onih djelatnosti za koje je ono registrirano kod nadležnog tijela državne uprave. Poslovanje podrazumijeva proizvodnju, potrošnju i raspodjelu proizvoda, usluga i dobara koje pravne osobe međusobno razmjenjuju.

11 Prema Nacionalnoj klasifikaciji djelatnosti 2007. (NKD 2007.) šifra djelatnosti knjižnica je 9101, a prema NKD 2002. 92511. Odluka o Nacionalnoj klasifikaciji djelatnosti 2007. - NKD 2007. // Narodne novine 58, 1870(2007). [citirano: 2019-08-6]. Dostupno na: https://narodnenovine.nn.hr/clanci/sluzbeni/2007_06_58_1870.html.
} 
la u tiskanom i/ili elektroničkom obliku, pohrana, čuvanje i zaštita knjižnične građe te provođenje mjera zaštite knjižnične građe koja je kulturno dobro, pružanje informacijskih usluga, posudba i davanje na korištenje knjižnične građe, uključujući međuknjižničnu posudbu, digitalizaciju knjižnične građe, usmjeravanje i podučavanje korisnika pri izboru i korištenju knjižnične građe, informacijskih pomagala i drugih izvora, vođenje dokumentacije i prikupljanje statističkih podataka o poslovanju, knjižničnoj građi, korisnicima i korištenju usluga knjižnice, pripremanje kulturnih, informacijskih, obrazovnih i znanstvenih sadržaja i programa, izrada biltena, kataloga, bibliografija i drugih informacijskih pomagala itd. ${ }^{12}$

(b) Rukovođenje materijalnim resursima, primjerice knjižnom građom, fondom ili zbirkom, nekretninama (zemljištima, zgradama, infrastrukturama), opremom, informatičkim i drugim tehnologijama, inventarom, vozilima, energentima, materijalima, sirovinama itd.

(c) Rukovođenje financijskim resursima, primjerice novcem, vrijednosnicama, potraživanjima, dugovanjima itd.

(d) Rukovođenje nematerijalnim i organizacijskim resursima, primjerice ljudskim potencijalima (odnosno uposlenicima i njihovim znanjima, vještinama i kompetencijama), raspoloživim radnim satima, raspoloživim poslovnim prostorima, pravima, licencama, informacijama, računalnim programima, uspostavljenim organizacijskim strukturama, organizacijskom kulturom, organizacijskom klimom, društvenom umreženošću, društvenim ugledom, knjižnicom kao pravnom osobom itd.

Premda smo prethodno razvrstali pojedine resurse organizacije na različite skupine, jedini pravi resurs za koji se može tvrditi da je temelj svih ostalih jesu ljudski potencijali. Novac se primjerice može posuditi od banke, prostor i oprema kupiti ili iznajmiti, dok se knjižničari trebaju ne samo obrazovati, osposobiti i uvesti u rad već i međusobno povezati u organizacijsku i funkcionalnu radnu zajednicu te izgraditi produktivnu organizacijsku kulturu i organizacijsku klimu. Drugim riječima, potrebno je vrijeme, jednako kao i za izgradnju knjižničnog fonda. Osim toga, ljudski potencijali jedini su od nabrojanih resursa koji se mogu razvijati i prilagođavati promjenama u okruženju te uvećavati ostale organizacijske resurse.

U organizacijskom, odnosno administrativnom smislu, dužnosti i odgovornosti ravnatelja koje se najčešće navode u statutima većine javnih knjižnica u Republici Hrvatskoj mogu se klasificirati u nekoliko skupina poslova:

12 Sadržaji pojedinih knjižničnih djelatnosti navedenih prema Nacionalnoj klasifikaciji djelatnosti 2007. (NKD 2007.) mogu se detaljnije sagledati sa stajališta knjižničarske struke, primjerice u Tadić, K. Rad u knjižnici: priručnik za knjižničare. Opatija: Naklada Benja, 1994. [citirano: 201908-6]. Dostupno na: http://dzs.ffzg.unizg.hr/text/katm.htm. 
(1) predlaže i ustrojava organizacijsku strukturu knjižnice

(2) organizira i nadzire rad i stručni rad u knjižnici

(3) upravlja resursima knjižnice (materijalnim, tehnološko-organizacijskim, financijskim, pravnim i radnim resursima)

(4) predlaže upravnom vijeću donošenje pravnih akata i stručnih dokumenata (statuta, pravilnika, izvješća o radu, programa rada i razvoja, mjera za unapređenje rada knjižnice itd.)

(5) zastupa knjižnicu u pravnom prometu.

Komparativnom analizom poslovanja u gospodarskim subjektima i ustanovama može se uočiti da u rukovođenju knjižnicama ravnatelji imaju znatno manje ovlasti nego što ih imaju izvršni direktori, odnosno menadžeri u gospodarskim subjektima. Razlika u njihovim ovlastima pripisuje se razlikama koje postoje između javnih ustanova i gospodarskih subjekata u pogledu njihova poslanja, svrhe, djelatnosti itd. Drugo važno obilježje dužnosti i odgovornosti ravnatelja u knjižnicama odnosi se na simbiozu ravnatelja i upravnih vijeća u donošenju rukovodećih odluka. Drugim riječima, ravnatelj ne može donositi neke od odluka bez upravnog vijeća niti upravno vijeće svoje odluke može provesti bez ravnatelja. Upravno vijeće tako je prva razina koja osigurava zakonit rad knjižnice kako ravnatelji ne bi donosili upravne, poslovne i stručne odluke koje nisu sukladne sa zakonu, statutom, pravilnicima ili zahtjevima knjižničarske struke.

Povezanost funkcije upravljanja, koje obnaša upravno vijeće knjižnica i rukovodeće funkcije ravnatelja, ustrojena je na način da su upravna vijeća prioritetno regulacijska i kontrolna tijela, koja omogućavaju donošenje onih odluka, izvješća, planova, programa, projekata ili dokumenata koji su sukladni zakonima, osnivačkim odlukama, statutu, pravilnicima te stručnim standardima knjižničnog poslovanja.

Takav odnos ravnatelja i upravnih vijeća pokazao se prikladnim u radu javnih ustanova, ali ponekad može biti uzrokom većeg ili manjeg sukobljavanja te posljedičnog usporavanja organizacijskog funkcioniranja knjižnice, osobito njezina organizacijskog razvoja. Mehanizam ovog međuodnosa ravnatelja i upravnog vijeća nije savršen, ali osigurava da u slučajevima kada te vrste organizacijskih sukoba eskaliraju i kada se više nikako ne mogu smatrati produktivnima one u pravilu ne dovedu do bitnog narušavanja redovite knjižnične djelatnosti. Ali ako potraju i proširuju se na stručna vijeća i druge zaposlenike, mogu biti jedan od uzroka narušavanja organizacijske klime u knjižnici i poremećenih međuljudskih odnosa.

\subsection{Osnovne kategorije rukovođenja}

Rukovođenje se kao skup operativnih poslovnih procesa u knjižnici ne razlikuje značajnije od rukovođenja u drugim ustanovama koje obavljaju neku od po- 
vjerenih društvenih funkcija. Rukovođenje u knjižnicama oslanja se na temeljne rukovodeće kategorije u bilo kojoj organizaciji, kao što su (1) autoritet (ovlaštenje), (2) odgovornost, (3) delegiranje te (4) hijerarhija. Autoritet, bio on linijski, stožerni ili funkcionalni, odnosno izvorni, izvedeni, statusni, karizmatični, stručni ili tradicionalni, predstavlja legitimno pravo rukovodilaca u knjižnici na omeđeno odlučivanje u uporabi resursa organizacije (imovine, financija, kadrova itd.) radi postizanja očekivanih ciljeva u knjižničnom poslovanju. ${ }^{13}$

Ako je autoritet rukovodioca ili drugih uposlenika jedna strana medalje, odgovornost je druga strana. Odgovornost rukovodioca ili uposlenika jest obveza obavljanja poslova i zadaća u traženoj i/ili propisanoj kvaliteti i kvantiteti sukladno pravnim, organizacijskim i etičkim normama. Odgovornost rukovoditelja je, kao i autoritet, slojevit pojam i može biti statusna, pravna, stručna, moralna i politička. ${ }^{14}$

Delegiranje autoriteta i odgovornosti, kao jedna od vrlo značajnih rukovodnih vještina, jest prenošenje poslova, zadaća i autoriteta s viših na niže razine organizacije koje su potom odgovorne za izvršavanje delegiranih poslova. Pritom je važno znati da se poslovi, zadaće i odgovornost mogu delegirati po cijeloj hijerarhijskoj vertikali, ali se odgovornost nikada ne može u potpunosti delegirati. ${ }^{15}$

Hijerarhija predstavlja zadani organizacijski sustav podređenosti i nadređenosti pojedinih organizacijskih jedinica, službi i pojedinaca u području službenih odnosa. Osim što se hijerarhija uspostavlja sukladno organizacijskom ustroju, sustavom rukovođenja i procesima poslovanja, ona ima svoje međuljudske aspekte koji se ogledaju u odnosima između suradnika, između rukovodilaca i uposlenika te između samih rukovodilaca. Pri uspostavi hijerarhije kao izraza povezanih rukovodećih, administrativnih i operativnih odnosa treba utvrditi tko je komu nadređen i tko komu povjerava poslove ili tko koga kontrolira, tko ima veći prioritet ili veći status. Hijerarhija odnosa može se ostvarivati subordinacijom, što je primjerno čvrstim linijskim odnosima kakvi su primjerice u vojsci ili u policiji, zatim koordinacijom, kada i dalje postoji organizacijska piramida, ali su prisutne povratne komunikacijske veze i horizontalno povezivanje službi, rukovodilaca i uposlenika, primjerice u organizacijama u kojima se traži timski rad kao što su knjižnice, liječnički timovi, znanstvene organizacije itd.

\subsection{Funkcije rukovođenja}

U funkcijskom smislu rukovođenje je operativna i izvršna funkcija upravljanja koja se odnosi na sljedećih šest područja: (1) planiranje, (2) odlučivanje, (3) organiziranje, (4) rukovođenje ljudskim potencijalima, (5) vođenje i (6) kontrola. U

13 Detaljnije u Grochla, E. Einführung in die Organisationstheorie. Stuttgart: Poeschel, 1978.

14 Usp. Sikavica, P. Organizacija. Zagreb: Školska knjiga, 2011. Str. 64.

15 Usp. Sikavica, P.; M. Novak. Poslovna organizacija. Zagreb: Informator, 1999. Str. 449. 
praksi se navedena područja ne odvijaju sukcesivno, već simultano te su isprepletena s različitim razinama međusobnog utjecaja i međusobne ovisnosti. Razmotrimo redom svaku od navedenih funkcija rukovođenja.

Planiranje, kao temelj organizacijskog ponašanja i organizacijske dinamike, ima osnovu svrhu predviđanja, povezivanja i uređivanja uzročno-posljedičnih organizacijskih elemenata, počevši od poslanja knjižnice, ciljeva, zadaća, resursa, zahtjeva okruženja do raspoloživog vremena s ciljem učinkovitog i uspješnog funkcioniranja organizacije, odnosno knjižnice. Planiranje je predviđanje i oblikovanje budućnosti organizacije u kojoj je ,unaprijed definiran tijek aktivnosti koji je neophodno slijediti da bi se postigli postavljeni ciljevi na najučinkovitiji način. Planiranje je proces koji je povezan s odlučivanjem." ${ }^{16}$

Uobičajene etape planiranja koje navodi stručna literatura i koje se mogu primijeniti u samostalnim knjižnicama jesu: (1) etapa analize, u kojoj se u zadanom rasponu vremena prikupljanju relevantni podaci, koji se zatim transformiraju u pokazatelje (postotke, indekse, stope itd.) radi njihove analize te zaključne kvantitativne i kvalitativne ocjene; (2) etapa projektiranja, odnosno predviđanje pojedinih ključnih parametara budućeg željenog stanja uz korištenje uobičajenih metoda projektiranja (primjerice prosudbe stručnjaka, metoda korelacije, komparacije itd.); (3) etapa verifikacije odnosi se na ugradnju izabranih i definiranih parametara u planske dokumente, pri čemu je potrebno provesti temeljitu i sveobuhvatnu ekspertnu raspravu na sjednici stručnog vijeća knjižnice; (4) etapa usvajanja i donošenja odluke o planu ili programu knjižnice, što je u nadležnosti upravnog vijeća; (5) etapa razrade plana koja sadrži aktivnosti detaljne operacionalizacije plana knjižnice tijekom koje se razrađuju vremenski elementi, primjerice hodogrami, vremenske lente, primjena tehnika mrežnog planiranja itd.; (6) etapa praćenja plana, rebalansi i njegove korekcije tijekom provođenja. ${ }^{17}$

Planove i razvojne programe u knjižnicama priprema i predlaže rukovodstvo u suradnji sa stručnim vijećem knjižnice, a usvaja ga upravno vijeće knjižnice. Godišnji operativni planovi i programi te godišnji financijski planovi knjižnica najčešće se odnose na sljedeća područja planiranja: izgradnja knjižničnih zbirki (nabava knjižnične građe, osiguravanje pristupa online bazama podatka), obrada knjižnične građe, zaštita knjižnične građe (preventivna i kurativna zaštita), plan upisa korisnika, posudba knjižnične građe, kulturne i promotivne djelatnosti, informacijsko-referalne djelatnosti, edukativna djelatnost za korisnike i knjižnične djelatnike, stručno usavršavanje i cjeloživotno obrazovanje, razvoj portala knjižnice, tuzemna i inozemna suradnja knjižnice, planiranje posebnih programa i projekata, planiranje kapitalnih ulaganja u prostore i opremu, planiranje investicij-

16 Mintzberg, H. Mintzberg on management - inside our strange world of organisations. New York: Prentice Hall, 1991.

17 Usp. Jurina, M. Organizacija i menadžment. Zaprešić: Visoka škola za poslovanje i upravljanje s pravom javnosti Baltazar Adam Krčelić, 2011. Str 145-149. 
skog održavanja te planiranje financiranja bruto plaća djelatnika i materijalnih rashoda knjižnice. Navedene etape i područja planiranja metodološki su slična prilikom godišnjeg, odnosno operativnog ili strategijskog, odnosno višegodišnjeg planiranja. Strategijsko planiranje sadržajno je složenije od operativnog, ponajviše zbog duljeg vremenskog horizonta planiranja u odnosu na godišnje, u kojem raste neizvjesnost projekcija razvoja, ponajviše zbog izvjesnih promjena u društvenom, ekonomskom, političkom i organizacijskom okruženju. Upravni odbori knjižnica, na prijedlog ravnatelja i uz prethodnu raspravu na sjednicama stručnog vijeća, usvajaju strateške petogodišnje planove koji u pravilu sadržavaju nekoliko programa, kao što su primjerice razvoj postojećih i uvođenje novih knjižničnih usluga, održavanje kulturno-promotivnih aktivnosti, unapređenje stručnih znanja i vještina knjižničnih djelatnika, izdavačka djelatnost, razvoj infrastrukture potrebne za knjižničnu djelatnost i slično.

Odlučivanje, kao temeljna rukovodna funkcija za koju su potrebna znanja, informacije i vještine, jest ,izbor između više mogućnosti, čime se određuju buduće akcije. "“18 Poslovne odluke, bile one strategijske, taktičke, operativne ili izvršne, rezultat su procesa odlučivanja. Ako su poznate sve činjenice, informacije i moguće okolnosti potrebne za odlučivanje, ono je tada determinističko. No praksa pokazuje da su najčešće poznate samo neke ili većina činjenica i informacija i tada je odlučivanje stohastičko. Osim što determinističko odlučivanje najčešće nije moguće, jednako tako nije moguće iz odlučivanja isključiti subjektivni čimbenik, pa u tom slučaju nastaju intuitivno, zatim prosudbeno i, na kraju, racionalno odlučivanje. ${ }^{19}$

Intuitivno odlučivanje rijetko se kada preporučuje, osim za donošenje operativnih odluka i rješavanje rutinskih zadaća, a temelji se na bogatom radnom i poslovnom iskustvu rukovoditelja $u$ istoj ili sličnoj poslovnoj situaciji te je mogućnost pogreške manja. Odlučivanje na temelju prosudbe prisutno je u poslovnim situacijama koje su međusobno slične ili iste i moguće ga je primijeniti u programiranom odlučivanju, primjerice za rješavanje ponavljajućih problema u poznatim situacijama i za koje postoje utvrđene procedure. Racionalno ili činjenično odlučivanje temelji se na postojanju potrebnih informacija te na nekom od postojećih teorijskih analitičko-logičkih modela. Ovo odlučivanje ima određeni broj etapa, a to su primjerice utvrđivanje i operacionalizacija željenog cilja, identifikacija problema, određivanje tipa odluke, znanstvena determinacija mogućih izbora, izbor jedne alternative, implementacija te kontrola.$^{20}$ Vrijednost racionalno-činjeničnog odlučivanja sastoji se od mogućnosti izbora između više mogućnosti koje se prosuđuju i vrednuju na temelju kvantitativnih činjenica i kvalitativnih informacija.

18 Luthans, F. Organizational behavior. New York: McGraw Hill, 1989. Str. 533.

19 Usp. Sikavica, P.; F. Bahtijarević-Šiber. Menadžment: teorija menadžmenta i veliko empirijsko istraživanje u Hrvatskoj. Zagreb: Masmedia, 2004. Str. 138.

20 Brekić, J. Inovativni menadžment. Zagreb: Alineja, 1994. Str. 104. 
Primjenjuje se pri donošenju taktičkih i strateških odluka te u postupcima neprogramiranog odlučivanja (u okolnostima koje se pojavljuju rijetko ili jedanput i za koje ne postoje procedure odlučivanja).

Kako je odlučivanje najvažnija zadaća upravnih tijela i rukovoditelja, ono se treba temeljito pripremati. Što je bolja raspoloživost potrebnih informacija i pažljivija priprema za odlučivanje, manje su mogućnosti donošenja krivih ili, još češće, nedovoljno ispravnih odluka. U slučaju krivih odluka, vrijeme i napor koji je bilo potrebno utrošiti na njihovu pripremu moći će koristiti u sanaciji posljedica, pod uvjetom da je to nakon donesene i provedene odluke uopće moguće. Iskusni rukovoditelji znaju da u odlučivanju treba uvijek imati razumnu mjeru opreza. ${ }^{21}$

Organiziranje, kao rukovodeća funkcija, sadrži podjelu ustanove na organizacijske jedinice (odjeli, službe, ogranci, čitaonice, bibliobus itd.) na temelju izabranih kriterija, primjerice funkcije, poslova, procesa, aktivnosti itd. Pri oblikovanju organizacijskih jedinica potrebno je odrediti temeljne dimenzije organizacijske strukture ustanove: razinu kompleksnosti, odnosno raspon organizacijske kontrole, razinu formalizacije (broj propisa o izvršavanju poslova, konkretizacija normi i način organizacijskog ponašanja) te razinu centralizacije ili decentralizacije upravljačkih i rukovodećih ovlasti u donošenju poslovnih odluka. Nakon toga potrebno je pojedinim organizacijskim jedinicama utvrditi organizacijske uloge, koje trebaju sadržavati provjerljive ciljeve organizacijskih jedinica, jasno definirane aktivnosti i dužnosti, područje ovlasti i sloboda u odlučivanju te odrediti informacije potrebne za odlučivanje. I na kraju, potrebno je uspostaviti mehanizme koordinacije između organizacijskih jedinica te uprave i rukovodstva, što se može postići na nekoliko načina: putem hijerarhije, putem utvrđenih pravila, programa i procedura, putem slobode odlučivanja ili smanjenjem raspona kontrole. ${ }^{22}$

Osim prethodno opisanih tzv. tvrdih čimbenika kojima se oblikuje struktura i funkcioniranje organizacije, potrebno je ukratko ukazati i na tzv. meke čimbenike koji čine organizacijsku kulturu i mogu bitno utjecati na procese upravljanja i rukovođenja u organizacijama. ${ }^{23}$ Organizacijska kultura je ,relativno trajan i specifičan sustav temeljnih oblika ponašanja, vrijednosti, uvjerenja, normi i običaja, koji određuje organizacijsko ponašanje, mišljenje i usmjerava sve aktivnosti pojedinca i grupa koje ih sačinjavaju. “" ${ }^{24}$ Potrebno je razlikovati organizacijsku kulturu

\footnotetext{
21 Više o odlučivanju u Sikavica, P.; T. Hunjak; N. Begičević Ređep; T. Hernaus. Poslovno odlučivanje. Zagreb: Školska knjiga, 2014.

22 Usp. Buble, M. Menadžment. Zagreb: Sinergija, 2006.

23 Fenomen organizacijske kulture počeli su istraživati Petters i Waterman. Vidjeti u Petters, T.

J.; R. H. Waterman. In search of excellence. New York: Harper and Row, 1982.

${ }_{24}$ Usp. Bahtijarević-Šiber, F.; Borović, S.; Buble, M.; Dujanović,M.; Kapustić, S. Organizacijska teorija. Informator, Zagreb 1991., str. 202.
} 
od organizacijske klime, koja je dio organizacijske kulture, ali je prioritetno izraz subjektivne kvalitete radne okoline, odnosno psihološke atmosfere koja ima određeni utjecaj na individualno i grupno ponašanje.

Pri izboru razine centralizacije organizacijske strukture, knjižnici je prikladniji centraliziraniji u odnosu na decentralizirani model. Prednosti decentralizacije pokazuju se tek u većim organizacijskim sustavima, kada je potrebno povećati učinkovitost organizacijskih jedinica, ubrzati odlučivanje, smanjiti troškove itd. Ona je prikladna primjerice u funkcioniranju knjižnično-informacijskog sustava, dok je u slučaju pojedinačnih knjižnica primjereniji centralizirani model, što dokazuje sama praksa. ${ }^{25}$

Uobičajeni i pojednostavljeni organizacijski model knjižnice prikazuje slika $1 .{ }^{26}$

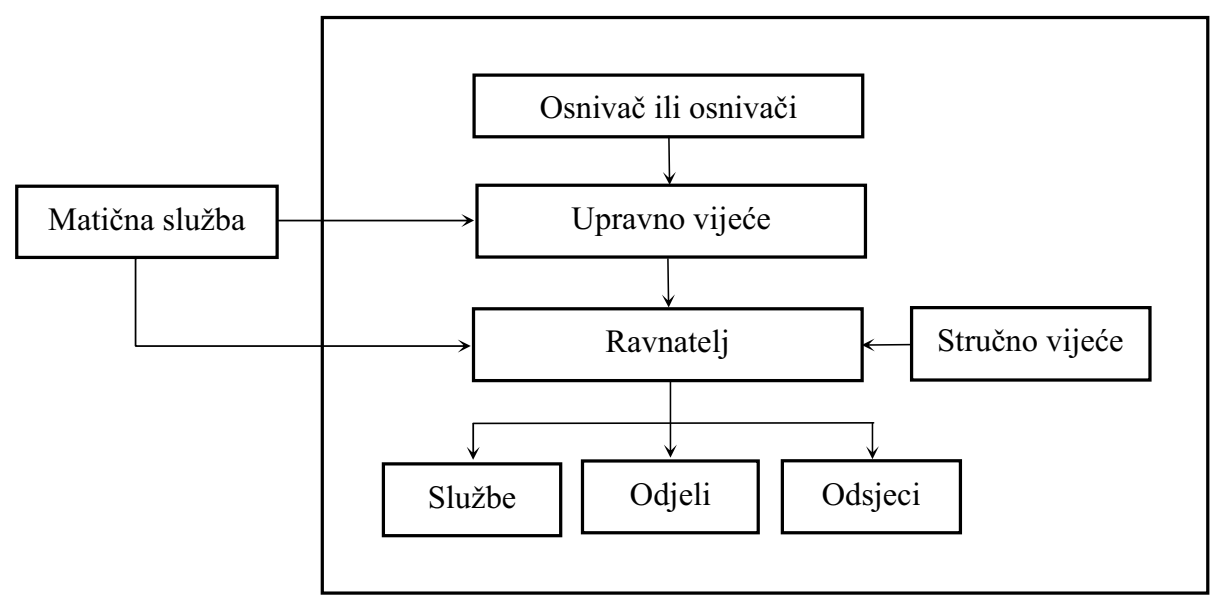

Slika 1. Organizacijski model knjižnice

Izvor: autor

25 Mihalić navodi da nova organizacija knjižnica „treba biti decentralizirana.“ Mihalić, M. Upravljanje promjenama kao uvjet razvoja digitalne knjižnice. // Vjesnik bibliotekara Hrvatske 45, 3-4(2002), str. 34. Međutim mišljenja smo da su prednosti centraliziranog modela organizacije knjižnice veće u odnosu na decentralizirani model. Razlozi za to su primjerice brže donošenje odluka, jedinstvenost procedura, bolje sagledavanje cjeline (poslanja, ciljeva, strategija, interesa) organizacije, odnosno ustanove, uspješnije izvođenje dugoročnog planiranja i praćenja rezultata itd. Za razliku od decentraliziranog modela, centralizirani je model u pravilu jeftiniji i osigurava učinkovitije rukovođenje. Međutim u velikim sustavima može razviti neželjene pojave kao što su birokratizam, sporost i krutost u odlučivanju te, općenito, značajno umanjiti učinkovitost organizacije.

26 Dobro je uočiti da je u prikazanom organizacijskom modelu knjižnice matična služba prikazana izvan njega. Dakle matična služba ne sudjeluje u upravljanju i/ili rukovođenju određenom knjižnicom, već ima ulogu pružanja stručne podrške. Drugim riječima, ona sudjeluje u radu knjižnice snagom stručnih argumenata. 
U cilju poboljšavanja organizacije knjižnica preporučljivo je na vidljivom mjestu u knjižnici postaviti organizacijsku shemu knjižnice (ili organigram) kao bi svim uposlenicima bila jasnija organizacijska struktura i njezino funkcioniranje. Organizacijska shema knjižnice jest pojednostavljeni grafički prikaz organizacijskog ustrojstva knjižnice u kojem su prikazane organizacijske jedinice i pozicije (odjeli, uredi, područne knjižnice, tijela upravljanja i rukovođenja, savjetodavna tijela itd.) te njihove međusobne veze i odnosi. Organizacijske jedinice, koje su predstavljene pravokutnicima, povezane su ili vodoravnim crtama, koje označavaju procesnu ili neku drugu povezanost na istoj hijerarhijskoj liniji razini, ili okomitim crtama, koje označavaju podređenost ili nadređenost. ${ }^{27}$

Rukovođenje ljudskim potencijalima (ljudskim resursima) u knjižnici obuhvaća knjižnično osoblje koje obavlja stručne knjižnične poslove te ostale uposlenike knjižnice u pomoćnim i pratećim službama. Povremeno u poslovanju knjižnice mogu sudjelovati studenti i učenici na stručnoj praksi, osobe na stručnom usavršavanju bez zasnivanja radnog odnosa, volonteri te počinitelji kaznenih djela koji izvršavaju svoju alternativnu kaznenu sankciju radom za opće dobro. Rukovođenje ljudskim potencijalima povezuje i usklađuje zadaće koje se odnose na osiguravanje potrebnog broja i strukture uposlenika s njihovim znanjima i vještinama, motivacijom i preferencijama te potrebnim organizacijskim oblicima ponašanja. ${ }^{28}$ Navedene zadaće klasificiraju se u pojedinačne skupine procesa. Prema V. Vujiću ti su procesi: projektiranje i analiza radnih mjesta, sustav planiranja i razvoja ljudskih potencijala, benchmarking ljudskih potencijala, pribavljanje i odabir, radni odnosi, politika zapošljavanja i uvođenja u posao, motivacija, inoviranje znanja, sustav vrednovanja postignuća djelatnika, razvoj osobne karijere i promocije te participativno upravljanje u poslovnim sustavima. ${ }^{29}$ Prethodno navedene skupine procesa mogu se, s određenim prilagodbama, primijeniti na upravljanje i rukovođenje ljudskim potencijalima u knjižnicama.

Pojedina područja knjižnične djelatnosti zakonodavac je u Republici Hrvatskoj normirao te je otuda u rukovođenju ljudskim potencijalima knjižnice potrebno oslanjati se na donesene dokumente. To su primjerice Zakon o knjižnicama koji u člancima 31. i 32. regulira posebnosti koje se odnose na knjižnično osoblje ${ }^{30}$, zatim Standardi za narodne knjižnice u Republici Hrvatskoj koji se u člancima od 31. do 37. odnose na knjižnično osoblje, Pravilnik o uvjetima i načinu stjecanja stručnih zvanja u knjižničnoj struci koji regulira stjecanje temeljnih i viših stručnih zvanja,

\footnotetext{
${ }^{27}$ Dodatne sadržaje vidjeti u Sikavica, P.; P. Hernaus. Dizajniranje organizacije: strukture, procesi, poslovi Zagreb : Novi informator, 2011.

28 Usp. Bahtijarević-Šiber, F. Menadžment ljudskih potencijala. Zagreb: Golden marketing, 1999. Str. 16.

29 Usp. Vujić, V. Menadžment ljudskog kapitala. Opatija: Fakultet za turistički i hotelijerski menadžment, 2004.

30 Zakon o knjižnicama i knjižničnoj djelatnosti. Nav. dj.
} 
polaganje stručnih ispita te mjerila za ocjenjivanje stručne osposobljenosti ${ }^{31}$, zatim pravilnici o ustrojstvu radnih mjesta pojedinih knjižnica koji utvrđuju potreban broj uposlenika i njihov radni, stručni i obrazovni profil itd.

Posebnu važnost u području upravljanja i rukovođenja ljudskim potencijalima u knjižnicama ima njihovo stalno stručno osposobljavanje, odnosno cjeloživotno učenje knjižničara i informacijskih stručnjaka i ostalih djelatnika. Matične knjižnice, Centar za stalno stručno osposobljavanje knjižničara, Nacionalna i sveučilišna knjižnica, Hrvatsko knjižničarsko društvo i Hrvatska udruga školskih knjižničara s ostalim partnerima predstavljaju izvrsnu platformu na kojoj se organiziraju i provode brojni bodovni tečajevi i organiziraju različiti projekti koji omogućuju uspješno ostvarivanje cjeloživotnog učenja i usavršavanja knjižničnih djelatnika te stabilan i uspješan razvoj njihovih karijera. ${ }^{32}$

Ostali procesi upravljanja i rukovođenja ljudskim potencijalima u knjižnicama znatno su manje normirani od prethodno razmatranih područja, pa su upravna vijeća i ravnatelji upućeni na opću stručnu literaturu iz ovoga područja. To se prvenstveno odnosi na proces definiranja opće politike korištenja i razvoja ljudskih potencijala, utvrđivanje potreba i planiranje ljudskih potencijala, pribavljanje i odabir (selekciju) knjižničara, ostalih djelatnika, volontera itd., zasnivanje radnog odnosa ili sklapanje ugovora o radu (o volontiranju, stručnom osposobljavanju bez zasnivanja radnog odnosa itd.), uvođenje djelatnika (volontera, pripravnika itd.) u posao, motiviranje djelatnika na rad uz istovremeno suzbijanje demotivacije, ocjenjivanje uspješnosti djelatnika te upravljanje organizacijskim promjenama. Proces benchmarkinga, kojim se poslovni subjekt uspoređuje s najboljima u svojoj djelatnosti, nema poslovni značaj kao u gospodarskim subjektima, s obzirom na to da knjižnice u svojoj djelatnosti nisu tržišno orijentirane i među njima nema tržišnog natjecanja. No usporedba s drugim knjižnicama može biti korisna za upravljanje i rukovođenje imajući u vidu potrebu uravnoteženog razvoja knjižničnog sustava Republike Hrvatske. Premda knjižnice nisu subjekti tržišnog natjecanja, one se već dugo nalaze u netržišnom natjecanju s drugim kulturnim, umjetničkim ili zabavnim djelatnostima nastojeći zadržati pozornost i naklonost svojih korisnika i financijera.

Vodstvo (engl. leadership), koje se zasniva na mehanizmima socijalne interakcije (imitacija, sugestija, stimulacija itd.), najčešće se opisuje kao sposobnost utjecaja na druge ljude kako bi oni bolje pridonijeli grupnim i zajedničkim ciljevima

\footnotetext{
31 Pravilnik ouvjetimainačinu stjecanja stručnih zvanja.//Narodnenovine 28, 584(2011). [citirano: 2019-08-6]. Dostupno na: https://narodne-novine.nn.hr/clanci/sluzbeni/2011_03_28_584.html.

32 Pažnje vrijedan rezultat jednog takvog projekta iz 2009. godine, koji su ostvarile Nacionalna i sveučilišna knjižnica u Zagrebu, Odsjek za informacijske znanosti Filozofskog fakulteta Sveučilišta u Zagrebu, Knjižnice grada Zagreba i Hrvatsko knjižničarsko društvo, jest publikacija Cjeloživotno učenje knjižničara: ishodi učenja i fleksibilnost. [citirano: 2019-086]. Dostupno na: http://www.nsk.hr/cuk/cuk.pdf?_ga=2.144923188.1433523705.15331918381470277859.1515137876 .
} 
organizacije u kojoj djeluju ili rade. ${ }^{33} \mathrm{Za}$ razliku od neformalnih vođa u neformalnim organizacijama, $u$ formalnim organizacijama (primjerice u poslovnim subjektima, ustanovama itd.) vodstvo ima sva obilježja poslovne funkcije rukovoditelja. U tom smislu rukovoditelji, neovisno o tome na kojem se hijerarhijskom stupnju u organizaciji nalaze, svojim sposobnostima utjecaja na uposlenike koordiniraju i ubrzavaju njihove skupne i pojedinačne aktivnosti, prenose na njih svoju viziju i oduševljenje inspirirajući ih na poletan rad, poboljšavaju unutarnju interakciju unutar grupa i između grupa, podižu radni moral te interveniraju u sprječavanju ili razrješavanju konflikata. Drugim riječima, rukovoditelji trebaju stjecati i razvijati vještine emocionalne i socijalne inteligencije, pazeći pritom na oprezno i odgovorno korištenje svoje organizacijske i liderske moći.

Ravnateljima knjižnica, koji rukovode organizacijom koja najvećim dijelom upošljava obrazovne i stručne djelatnike, primjereni su participativni i demokratski stil vođenja, a treba izbjegavati, koliko god je to moguće, autokratsko-eksploatatorski stil te benevolentno-autoritarni stil vođenja. Participativni i demokratski stil obilježava povjerenje prema podređenima, uključenost podređenih u donošenje odluka, primjenjuje se blaži oblik subordinacije, motivira ih se pomoću nagrada i priznanja te se međusobno razmjenjuju poslovne ideje i stručna mišljenja. ${ }^{34} \mathrm{U}$ pojedinim organizacijskim dijelovima knjižnice ili pri planiranju i provođenju pojedinih projekata uputno je uspostaviti i razvijati timski rad kao dio funkcije vodstva. ${ }^{35}$

Kontrola, kao upravljačka i rukovodeća funkcija, nerijetko je značajno zanemarena, premda ju organizacijska znanost i praksa smatraju jednom od osnovnih poslovnih funkcija. Ona se treba planirati i ugraditi u knjižnično poslovanje, kao i u ostale poslove knjižnice (upravljanje imovinom, ljudskim potencijalima, financijskim sredstvima, tehnologijama itd.) jer je to proces kojim se provjeravaju postojeći standardi na način da se mjere vlastiti učinci i rezultati u odnosu na standarde te se uspoređuju ostvareni rezultati s postavljenim operativnim i strateškim ciljevima. Na temelju tako dobivenih rezultata pokreću se korektivni postupci i donose mjere poboljšanja organizacijskog ponašanja u knjižnici.

Kao jednu od mjera kontrole upravni odbori knjižnica usvajaju godišnja izvješća čiji sadržaji prate sadržaje godišnjih planova. Godišnja izvješća znatno bi se poboljšala kada bi se koristili brojčani iznosi pojedinih pojava unatrag pet ili više godina i tako pratio trend pojave. Također, korisno bi bilo uspoređivati pojedina statistička obilježja pojedine knjižnice s prosjekom tog obilježja na razini Hrvatske, koji se može pronaći u izvješćima o knjižnicama Državnog zavoda za statistiku Republike Hrvatske ili izvješćima matičnih knjižnica koja se dostavljaju na daljnju obradu Nacionalnoj i sveučilišnoj knjižnici kao matičnoj knjižnici na

33 Usp. Weichrich, H.; H. Koontz. Menedžment. Zagreb: Mate, 1998. Str. 460.

34 Usp. Jurina, M. Nav. dj., str. 281.

35 Usp.. Tudor, G.; V. Srića. Menadžer i pobjednički tim: čarolije timskog rada. Zagreb: M.E.P., 2014. 
nacionalnoj razini. ${ }^{36}$ Takva vrsta kontrole naziva se naknadna ili završna kontrola i njome se mjere rezultati tako što se uspoređuju s planiranim ciljevima. Testne kontrole ili fazne kontrole vrše se tijekom poslovne godine ili tijekom petogodišnjeg planskog razdoblja i imaju svrhu izbjegavanja pogrešaka koje bi se mogle akumulirati protokom vremena. Najuspješniji je anticipativni tip kontrole, kojIm se nastoje izbjeći greške prije nego se dogode, no njega je najteže projektirati i potom izvesti.

\section{Simbioza poslovnih i rukovodećih funkcija u knjižnici}

Ravnatelji knjižnica rukovode poslovnim procesima u zadanim organizacijskim okvirima knjižnice, usklađujući ih s postojećim materijalnim, financijskim i nematerijalnim resursima, koristeći se sukcesivno i simultano pojedinim funkcijama rukovođenja. Primjerice planiranje se primjenjuje na svako od navedenih poslovnih područja rukovođenja, odnosno na područje knjižničnog poslovanja, područje financijskog poslovanja i računovodstva, općih poslova, informatičke potpore, materijalnih resursa itd. Jednako tako funkcije organiziranja i odlučivanja, kadrovskog popunjavanja, vodstva i kontrole primjenjuju se na područja poslovanja. Međusobni odnosi funkcija rukovođenja i područja rukovođenja pojednostavljeno su prikazani na slici 2 kao dvodimenzionalna matrica.

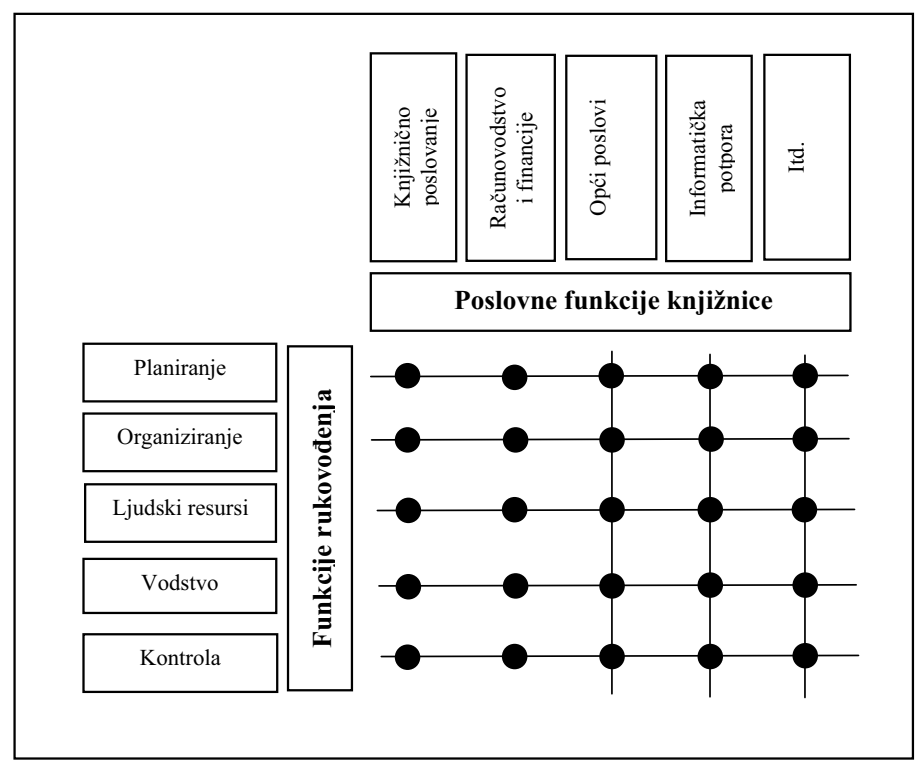

Slika 2. Matrica odnosa rukovodnih funkcija i poslovnih funkcija Izvor: autor

36 Primjerice Izvješće o radu županijskih matičnih službi za školske knjižnice za 2014. godinu. [citirano: 2019-08-6]. Dostupno na: http://www.nsk.hr/maticna-sluzba-za-skolske-knjiznice/. 
Crte rukovodećih i poslovnih funkcija u svojim sjecištima prikazuju čvorišta koja označavaju pojedinačne funkcije rukovođenja primijenjene na pojedinačna poslovna područja. Prikazana matrica implicira da je posao rukovoditelja izrazito raznolik, složen i otuda zahtjevan.

Jedan od sveobuhvatnijih prikaza sadržaja posla rukovoditelja koji se, uz manje prilagodbe, može primijeniti i na ravnatelje knjižnica prikazan je u tablici 1.

Tablica 1. Uobičajeni poslovi rukovoditelja ${ }^{37}$

\begin{tabular}{|l|l|}
\hline Aktivnosti & Opis \\
\hline Simbolične & $\begin{array}{l}\text { Aktivnosti u kojima rukovoditelj simbolično ili } \\
\text { ceremonijalno predstavlja jedinicu ili organizaciju. }\end{array}$ \\
\hline $\begin{array}{l}\text { Razvoj i obrazovanje } \\
\text { zaposlenih }\end{array}$ & $\begin{array}{l}\text { Odlučivanje o organiziranju i organiziranje } \\
\text { obrazovnih i razvojnih aktivnosti za sebe, zaposlene } \\
\text { ili organizaciju; obavljanje uloge mentora. }\end{array}$ \\
\hline $\begin{array}{l}\text { Praćenje i pribavljanje } \\
\text { informacija (monitoring) }\end{array}$ & $\begin{array}{l}\text { Prikupljanje i pribavljanje informacija o napretku } \\
\text { posla; praćenje odstupanja. }\end{array}$ \\
\hline Distribucija informacija & $\begin{array}{l}\text { Informiranje drugih o aktivnostima jedinice ili } \\
\text { organizacije; distribuiranje važnih informacija. }\end{array}$ \\
\hline Poduzetnik & $\begin{array}{l}\text { Nalaženje ili kreiranje mogućnosti za poboljšanje } \\
\text { radnih aktivnosti i razvoj. }\end{array}$ \\
\hline Alokacija resursa & $\begin{array}{l}\text { Uporaba dostupnih resursa (ljudskih, tehničkih, } \\
\text { mehaničkih, fizičkih, financijskih) za postizanje } \\
\text { poslovnog uspjeha. }\end{array}$ \\
\hline Brzo reagiranje na probleme & $\begin{array}{l}\text { Poduzimanje neposredne akcije na pojavu ozbiljnih } \\
\text { problema. }\end{array}$ \\
\hline Uvjeravanje & $\begin{array}{l}\text { Uporaba utjecaja za dobivanje kontrole nad silama } \\
\text { koje se ne mogu izravno kontrolirati. }\end{array}$ \\
\hline Strukturiranje i oblikovanje & $\begin{array}{l}\text { Mijenjanje organizacijske strukture da bi se } \\
\text { poboljšali radni procesi. }\end{array}$ \\
\hline Rutinska administracija & Vođenje brige o formalnim zahtjevima. \\
\hline Stvaranje mreže odnosa & $\begin{array}{l}\text { Povezivanje i sudjelovanje u aktivnostima radi } \\
\text { stvaranja potencijalno korisnih kontakata. }\end{array}$ \\
\hline Prekidi i smetnje & $\begin{array}{l}\text { Događaji koji oduzimaju vrijeme, a nisu povezani s } \\
\text { organizacijskim ciljevima. }\end{array}$ \\
\hline
\end{tabular}

Prema sadržaju tablice 1 može se zaključiti da rukovodeći poslovi, koji su mnogobrojni, raznoliki, kreativni, rutinski, zanimljivi ili dosadni, traže ravnatelja koji je s jedne strane stručnjak za knjižnično poslovanje, a s druge strane „speci-

37 Usp. Cascio, N. F. Applied psychology in personal management. 3. izd. Englewood Cliffs: Prentice-Hall, 1987. Str. 266-267. Citirano prema: Bahtijarević-Šiber, F. Nav. dj., str. 448-449. 
jalist opće prakse“ od kojega se očekuje posjedovanje brojnih vještina te odsustvo nekih osobina ličnosti. Od rukovoditelja se, između ostalog, očekuje da posjeduje sljedeće opće vještine: (1) administrativne (planiranje, izvršenje i kontrola te odlučivanje), (2) tehničko-stručne vještine (primjena znanja, kontrola kvalitete rada, rješavanje problema i kreativnost), (3) vodstveno-interpersonalne vještine (osjetljivost za ljude, motivacija, podučavanje, postavljanje ciljeva, timski rad, vrednovanje ljudi i razvoj suradnika), (4) komunikacijske vještine (usmene, pisane, slušanje i prezentacija), (5) dijagnostičko-analitičke vještine (identificiranje problema, analiza problema, rješenje problema i uočavanje promjena) te (6) strategijsko-konceptualne vještine (kreiranje vizije, sagledavanje cjeline i holistički pristup, određivanje prioriteta, dugoročna perspektiva i upravljanje promjenama). S druge strane rukovoditelj (ili ravnatelj) ne smije imati neke osobine ličnosti kao što su agresivnost, egocentričnost, depresivnost, autoritativnost, nesigurnost, konformizam, neodlučnost itd., već je poželjno da je energičan, ambiciozan, inteligentan, socijalno osjetljiv, poslovno orijentiran, samopouzdan, tolerantan na stres, kreativan, analitičan, uvjerljiv i prodoran, odlučan, fleksibilan i prilagodljiv, odlučan, komunikativan, srdačan, motiviran itd. ${ }^{38}$

Sagledavajući popis prethodno pobrojanih dužnosti, znanja i vještina, poželjnih i nepoželjnih osobina ličnosti koje se očekuju od nekog ravnatelja, postaje upitno mogu li se sva navedena svojstva pronaći u jednoj osobi. Vjerojatno se ne bi uvijek pronašli sve navedene kvalitete, ali bi velika većina trebala biti prisutna u dovoljnoj mjeri potrebnoj za uspješno rukovođenje. Iskustva pokazuju da je bolje kada neki ravnatelj ima većinu kvaliteta koje bi se mogle smatrati dovoljnima nego nekoliko njih ili sve izvrsne kvalitete, ali uz njih i dva ili tri obilježja koja su izrazito negativna, primjerice agresivnost, sklonost manipuliranju uposlenicima, upitnu etičnost i tomu slično.

Na tragu dvojbe trebaju li ravnatelji knjižnica biti prioritetno poznavatelji knjižničarske struke ili ekonomisti obrazovani za poslovanje i upravljanje, odnosno stručnjaci u području menadžmenta, ovaj autor smatra da je za učinkovitost $\mathrm{i}$ uspješnost knjižnice kao ustanove bolje ako su ravnatelji osobe s knjižničarskim obrazovanjem i iskustvom rada u knjižnici. Međutim rukovodeće (ili menadžerske) sposobnosti oni mogu i trebaju postupno stjecati polazeći različite programe cjeloživotnog učenja te stječući iskustvo tijekom rada. Znajući da složenost ravnateljskih funkcija raste s veličinom knjižnica te da se profili rukovodećih poslova međusobno razlikuju u odnosu na vrste knjižnica (nacionalnih, visokoškolskih, općeznanstvenih, narodnih (pučkih), školskih ili specijalnih knjižnica), sadržaji i obujmi potrebnih rukovodećih (menadžerskih) znanja međusobno će imati odgovarajuće razlike. Isto tako, dobro je

38 Usp. Burack, E. H.; N. J. Mathys. Career management in organizations: a practical human resource planning approach. Lake Forest: Brace-Park Press, 1980. Str. 92-92. Citirano prema: Bahtijarević-Šiber, F. Nav. dj., str. 454-455. 
nastaviti s izvođenjem odgovarajućeg broja kolegija tijekom studija knjižničarstva, a koji se odnose na upravljanje i rukovođenje. ${ }^{39}$

Ravnateljima knjižnica u njihovoj rukovodećoj funkciji koja se odnosi na knjižničnu djelatnost stručnu podršku pružaju stručna vijeća. Na njih knjižnice i knjižnice u sastavu, ako imaju više od pet zaposlenika, obvezuje članak 21. Zakona o knjižnicama i knjižničnoj djelatnosti. Stručna vijeća nemaju formalne upravljačke i rukovodne ingerencije, ali se odluke koje donose nositelji upravljačkih i rukovodećih tijela trebaju temeljiti na stručnim prosudbama, prijedlozima i preporukama stručnih vijeća knjižnica. Stabilna simbioza i unutarnja ravnoteža upravnih, rukovodnih i stručnih odluka treba osiguravati funkcionalno knjižnično poslovanje. ${ }^{40}$

Međutim stručna podrška ravnateljima i ostalim rukovodećim dužnosnicima u knjižnicama, koja se odnosi na organizacijske, upravljačke i rukovodeće (menadžerske) aktivnosti, manje je prisutna od stručne podrške koja se odnosi na obavljanje knjižničarske djelatnosti. U tom pogledu knjižničarski dužnosnici najčešće su usmjereni na samostalno snalaženje, razmjenu iskustava s drugim ravnateljima, pronalaženje rješenja u sadržajima stručne literature te na konzultiranje s članovima upravnih i stručnih vijeća. Olakotna je okolnost u tome što knjižnice ne posluju u tržišnom okuženju te su im izvori financiranja malokad u nekom od poslovnih rizika. Premda su prisutne izvjesne fluktuacije i manje neizvjesnosti u dotoku financijskih sredstava, može se reći da je rukovođenje neknjižničnim djelatnostima knjižnica ipak manje složena aktivnost nego što je slučaj u nekim drugim javnim službama. ${ }^{41}$

\section{Zaključak}

(1) Rukovođenje je poslovna funkcija koja ima za svoju temeljnu svrhu operacionalizirati upravljačke odluke vlasnika ili osnivača knjižnice, odnosno učinkovito i uspješno povezati upravljačke odluke s izvršnim funkcijama. To je organizacijski složena, intelektualno zahtjevna i vremenski trajna funkcija za koju su potrebna specifična znanja, vještine i kompetencije. Ravnatelji svoje dužnosti obavljaju tijekom unaprijed omeđenog razdoblja, koje u pravilu traje četiri godine.

39 O navedenoj dvojbi provedeno je zanimljivo istraživanje. Vidjeti u: Erl, V.; K. Petr. Ravnatelji knjižnica - poznavatelji struke i/ili menadžeri. // Vjesnik bibliotekara Hrvatske 45, 3-4(2002), str. 65-74.

${ }^{40}$ O stručnoj podršci ravnateljima knjižnica u rukovođenju knjižničnom djelatnošću vidjeti detaljnije u: Balog, A. Nav. dj., str. 89-93.

${ }_{41}$ Pojedini knjižničari povremeno se zainteresiraju za teme iz područja upravljanja i rukovođenja u knjižnicama. Primjerice Sečić, D. Upravljanje hrvatskim knjižnicama: prilog raspravi o nekim suvremenim problemima. // Vjesnik bibliotekara Hrvatske 45, 3-4(2002), str. 39-50. Zatim Ivanović, M. Prepoznavanje knjižničnoga marketinga. // Vjesnik bibliotekara Hrvatske 45, 3-4(2002), str. 105-116. Također, Petrak, J.; H. Markulin. Voditi, a biti vođen! Položaj i ovlasti voditelja knjižnica visokih učilišta. // Vjesnik bibliotekara Hrvatske 45, 3-4(2002), str 75-82. 
Jedan je od razloga i taj što su rukovodeće funkcije naporne i malokad se mogu obavljati tijekom glavnine radnog vijeka.

(2) Svaki član upravnog vijeća trebao bi prije početka svoga mandata ili, najkasnije, na njegovu početku, završiti odgovarajuću obuku iz najmanje tri područja. Ta su područja sljedeća: (1) osnove knjižničnih djelatnosti, (2) upravljanje i rukovođenje knjižnicama i (3) dužnosti i odgovornosti članova upravnih vijeća knjižnice, $\mathrm{i}$ to ne nužno navedenim redoslijedom. Isto tako potrebno je da si ravnatelji knjižnica osiguraju ciklične edukacije iz sljedećih područja: (1) upravljanja i rukovođenja (osobito rukovođenja ljudskim potencijalima), (2) knjižničnih djelatnosti i (3) informacijskih tehnologija.

(3) Organizacijska uspješnost i učinkovitost knjižnica te njihovo organizacijsko ponašanje ne odudara od prosjeka hrvatske stvarnosti. Premda ima posebno istaknutih primjera, knjižnice prate opće trendove društvenog razvoja te, s manjim zakašnjenjem, sudbinu gospodarskog razvoja. Drugim riječima, eventualni ekonomski prosperitet nacionalne ili lokalne ekonomije, najčešće u obliku punjenja gradskog ili općinskog proračuna povećanim prirezima porezu na dohodak, knjižnice će osjetiti s izvjesnim vremenskim odmakom, koji se u našim prilikama češće mjeri godinama nego mjesecima.

(4) Područja koja bi se mogla dodatno istražiti odnose se na razvoj metodologije, s pouzdanim, valjanim i prikladno baždarenim instrumentima prikladnim za mjerenje utjecaja knjižnica na kulturni, obrazovni, znanstveni i opći društveni razvoj te na njegov ekonomski rast. Rezultati mjerenja društvene uloge knjižnica i njihova trajnog i dugoročnog utjecaja na opći društveni razvoj vjerojatno bi imali značajan, a možda i presudan utjecaj na percepciju donositelja odluka o financiranju knjižnica.

(5) Potrebno je nadalje istražiti normativne i stvarne organizacijske aspekte $u$ knjižnicama, odnosno razlike koje se pojavljuju između propisanih organizacijskih, upravljačkih, rukovodećih i poslovnih procesa te izvedenih, odnosno onih stvarnih, koji su prisutni u svakodnevnom funkcioniranju. Razlike između propisanog (preskriptivnog) i stvarnog (deskriptivnog) organizacijskog ponašanja uvijek će biti prisutne u svakom stohastičkom sustavu, pa tako i u ljudskoj organizaciji. Međutim potrebno je utvrditi prihvatljivu razinu njihova odstupanja.

(6) Nadalje, potrebno je odrediti kriterij (ili više njih) kojim će se utvrditi razina odstupanja normativnog od stvarnog (empirijskog) organizacijskog ponašanja. Taj kriterij mogao bi biti broj utrošenih sati izvršenog organizacijskog napora, odnosno vrijednost radnih sati izražena u nacionalnoj valuti (trenutno u hrvatskim kunama). U slučaju da je vrijednost uloženog organizacijskog napora manja od utvrđene ili procijenjene vrijednosti koja nastaje radi utvrđene razlike normativnog i stvarnog organizacijskog ponašanja, oportuno je pristupiti uklanjanju čimbenika koji ih uzrokuju. Kada je taj iznos manji, tada se može smatrati da je odstupanje 
stvarnog od normativnog organizacijskog ponašanja u prihvatljivim granicama. Iskustvo potvrđuje da se, kada je percepcija odstupanja stvarnog od normativnog mala ili neznatna, u pravilu ne razmatraju ni ne poduzimaju organizacijske mjere usklađivanja.

(7) I na kraju, potrebno je utvrditi čimbenike koji uzrokuju raskorak između normativnog i stvarnog, odnosno preskriptivnog i deskriptivnog organizacijskog ponašanja, zatim ih detaljno opisati, utvrditi im uzroke te ih klasificirati prema izabranom kriteriju.

\section{LITERATURA}

Bahtijarević-Šiber, F. Menadžment ljudskih potencijala, Zagreb: Golden marketing, 1999.

Bahtijarević-Šiber, F.; Borović, S.; Buble, M.; Dujanović,M.; Kapustić, S. Organizacijska teorija. Informator, Zagreb 1991.

Balog, A. Upravljanje knjižnicom kao poslovna funkcija. // Vjesnik bibliotekara Hrvatske 61, 2(2018), 73-97.

Brekić, J. Inovativni menadžment. Zagreb: Alineja, 1994.

Buble, M. Menadžment. Zagreb: Sinergija, 2006.

Burack, E. H.; N. J. Mathys. Career management in organizations: a practical human resource planning approach. Lake Forest: Brace-Park Press, 1980.

Cascio, N. F. Applied psychology in personal management. 3. izd. Englewood Cliffs: Prentice-Hall, 1987.

Cjeloživotnoučenjeknjižničara: ishodiučenjaifleksibilnost. [citirano:2019-08-6].Dostupno nahttp://www.nsk.hr/cuk/cuk.pdf?_ga=2.144923188.1433523705.15331918381470277859.1515137876 .

Drucker, P. Najvažnije o menadžmentu: izbor iz radova o menadžmentu Petera F. Druckera. Zagreb: M.E.P. Consult, 2005.

Erl, V.; K. Petr. Ravnatelji knjižnica - poznavatelji struke i/ili menadžeri. // Vjesnik bibliotekara Hrvatske 45, 3-4(2002), 65-74.

Grochla, E. Einführung in die Organisationstheorie. Stuttgart: Poeschel, 1978.

Ivanović, M. Prepoznavanje knjižničnoga marketinga. // Vjesnik bibliotekara Hrvatske 45, 3-4(2002), 105-116.

Jurina, M. Organizacija i menadžment. Zaprešić: Visoka škola za poslovanje i upravljanje s pravom javnosti Baltazar Adam Krčelić, 2011.

Line, M.B. The universal library report. // Library mangement 17, 1(1996), 33-36. 
Luthans, F. Organizational behavior. New York: McGraw Hill, 1989.

Markulin, H.; M. Šember.; J. Petrak. Medicinske knjižnice na putu prema promjenama. // Vjesnik bibliotekara Hrvatske 45, 3-4(2002), 51-57.

Mihalić, M. Upravljanje promjenama kao uvjet razvoja digitalne knjižnice. // Vjesnik bibliotekara Hrvatske 45, 3-4(2002), str. 24-38.

Mintzberg, H. Mintzberg on management - inside our strange world of organistions. New York: Prentice Hall, 1991.

Odluka o Nacionalnoj klasifikaciji djelatnosti 2007. - NKD 2007. // Narodne novine 58, 1870(2007). [citirano: 2019-08-6]. Dostupno na: https://narodne-novine.nn.hr/ clanci/sluzbeni/2007_06_58_1870.html.

Petrak, J.; H. Markulin. Voditi, a biti vođen! Položaj i ovlasti voditelja knjižnica visokih učilišta. // Vjesnik bibliotekara Hrvatske 45, 3-4(2002), 75-82.

Petters, T. J.; R. H. Waterman. In search of excellence. New York: Harper and Row, 1982.

Pravilnik o uvjetima i načinu stjecanja stručnih zvanja. // Narodne novine 28, 584(2011). [citirano: 2019-08-6]. Dostupno na: https://narodne-novine.nn.hr/clanci/sluzbeni/2011_03_28_584.html.

Sečić, D. Upravljanje hrvatskim knjižnicama: prilog raspravi o nekim suvremenim problemima. // Vjesnik bibliotekara Hrvatske 45, 3-4(2002), str. 39-50.

Sikavica, P.; T. Hunjak; N. Begičević Ređep; T. Hernaus. Poslovno odlučivanje. Zagreb: Školska knjiga, 2014.

Sikavica, P. Organizacija. Zagreb: Školska knjiga, 2011.

Sikavica, P.; F. Bahtijarević-Šiber. Menadžment: teorija menadžmenta i veliko empirijsko istraživanje u Hrvatskoj. Zagreb: Masmedia, 2004.

Sikavica, P.; P. Hernaus. Dizajniranje organizacije: strukture, procesi, poslovi. Zagreb: Novi informator, 2011.

Sikavica, P.; M. Novak. Poslovna organizacija. Zagreb: Informator, 1999.

Tadić, K. Rad u knjižnici: priručnik za knjižničare. Opatija: Naklada Benja, 1994. [citirano: 2019-08-6]. Dostupno na: http://dzs.ffzg.unizg.hr/text/katm.htm.

Tudor, G.; V. Srića. Menadžer i pobjednički tim: čarolije timskog rada. Zagreb: M.E.P., 2014.

Vujić, V. Menadžment ljudskog kapitala. Opatija: Fakultet za turistički i hotelijerski menadžment, 2004.

Weichrich, H.; H. Koontz. Menadžment. Zagreb: Mate, 1998.

Zakon o knjižnicama i knjižničnoj djelatnosti. // Narodne novine 17, 365(2019). [citirano: 2019-08-6]. Dostupno na https://narodne-novine.nn.hr/clanci/sluzbeni/2019_02_17_356.html. 